\title{
The Effect of RES Blockade on Red Blood Cell Survival
}

\author{
Tatsumi Uchida, Shin Matsuda, Tetsugoro Tanaka, \\ Tadashi Sato, Tokuo Yut, Reiko Kokubun, Masashi \\ Kumano and Shigeo Kariyone \\ The First Department of Internal Medicine, Fukushima \\ Medical College, Fukushima 960
}

Uchida, T., Matsuda, S., Tanaka, T., Sato, T., Yui, T., Kokubun, R., Kumano, M. and KariYone, S. The Effect of RES Blockade on Red Blood Cell Survival. Tohoku J. exp. Med., 1981, 135 (3), 247-253 — The effect of RES blockade on the survival of heat-damaged and antibody coated red blood cells was evaluated in $\mathrm{C} 3 \mathrm{H}$ mice. RES function of $\mathrm{C} 3 \mathrm{H}$ mice was determined by the survival of ${ }^{59} \mathrm{Fe}$-labeled, heat-damaged red blood cells at $49^{\circ} \mathrm{C}$ for $30 \mathrm{~min}$. When animals were treated with an intravenous injection of non-labeled, heatdamaged red blood cells for the blockade of RES, red blood cell destruction was depressed in non-splenectomized and splenectomized mice. In the survival or organ distribution of ${ }^{59} \mathrm{Fe}-$-labeled, antibody-coated red blood cells, no difference was noted between animals with and without blockade. These findings suggest that heat-damaged red blood cells were destructed predominantly in the splenic RES and antibody coated cells were not broken down only by the splenic RES. - RES blockade; red blood cell survival; heat-damaged red blood cells; antibody-coated red blood cells; splenectomy

Measurement of disappearance curves of intravenously injected heat-damaged red blood cells is useful as a means of assessing reticuloendothelial system (RES) function. The present study is an attempt to evaluate the role of RES in red blood cell destruction, especially in the spleen. A modification of the technique employed by Murray (1963) was utilized in $\mathrm{C} 3 \mathrm{H}$ mice. The RES was blockaded with heatdamaged red blood cells and the effectiveness of the blockade was tested by the subsequent injection of tracer dose of ${ }^{59} \mathrm{Fe}$-labeled red blood cells. The role of the spleen was evaluated in non-splenectomized and splenectomized animals.

\section{Materials and Methods}

${ }^{59} \mathrm{Fe}$-labeled red blood cells. In vivo ${ }^{59} \mathrm{Fe}$-labeled red blood cells were prepared in $\mathrm{C} 3 \mathrm{H}$ mice by injecting $15 \mu \mathrm{Ci}$ of ${ }^{59} \mathrm{FeCl}_{3}$ intraperitoneally. Four days after the injection, the animals were sacrificed and heparinized blood was removed. After 3 washes in normal saline, ${ }^{59} \mathrm{Fe}-$ labeled red blood cells were suspended in saline.

Heat-damaged red blood cells. ${ }^{59} \mathrm{Fe}$-labeled red blood cells were heated at $49^{\circ} \mathrm{C}$ or $52^{\circ} \mathrm{C}$ for $30 \mathrm{~min}$, then they were injected into a tail vein of $\mathrm{C} 3 \mathrm{H}$ mice. Two hr after

Received for publication, December 23, 1980.

Correspondence; Tatsumi Uchida, M.D. The First Department of Internal Medicine Fukushima Medical College 4-45, Sugizuma-cho, Fukushima 960, Japan. 
injection, the animals were sacrificed, and the radioactivity of liver and spleen was counted. Since the red blood cells heated at $49^{\circ} \mathrm{C}$ caused a higher spleen-to-liver ratio of radioactivity than those heated at $52^{\circ} \mathrm{C}$ (see Results), the proper duration of heat damage was examined only at $49^{\circ} \mathrm{C}$ as follows: Red blood cells which were heated at $49^{\circ} \mathrm{C}$ for 5,15 , 30,45 and $90 \mathrm{~min}$ were infused intravenously in 5 groups of mice. The clearance rate and organ distribution of the red blood cells were examined $2 \mathrm{hr}$ after the infusion.

Blockade of RES. Specific depression of RES by heat-damaged red blood cells was performed. The heat-damaged red blood cells are believed to blockade the RES through direct action on the phagocytic cells (Stuart 1970). The method of pretreatment with an intravenous injection of heat-damaged red blood cells is shown in Fig. 1. ${ }^{51} \mathrm{Cr}$-labeled red blood cells of $\mathrm{C} 3 \mathrm{H}$ mice were used for this study. Six to $7 \mathrm{ml}$ of whole blood was incubated with $100 \mu \mathrm{Ci}$ of $\mathrm{Na}_{2}{ }^{51} \mathrm{CrO}_{4}$ at $37^{\circ} \mathrm{C}$ for 30 min. After labeling, the cells were washed twice with physiological saline, followed by incubation at $49^{\circ} \mathrm{C}$ for a predetermined period. To each animal, $0.2 \mathrm{ml}$ of heat-damaged cells was infused intravenously, and the clearance rate was observed.

Red cell destruction in control and RES-blockaded animals. Red cell destruction in RES-blockaded animals was examined as follows: $0.2 \mathrm{ml}$ of ${ }^{59} \mathrm{Fe}$-labeled heat-damaged cells was infused in the animals either pretreated or not pretreated with an intravenous injection of $0.6 \mathrm{ml}$ non-labeled damaged cells. Similar experiments were also done in splenectomized animals. The clearance and organ distribution of labeled cells were examined.

In order to evaluate antibody-related red blood cell destruction, anti-C3H-erythrocyte serum was prepared by the method of Nishioka (1974). Red cell stroma from C3H mice was injected into a rabbit intravenously twelve times at predetermined intervals and 32 days after the first injection, the serum was obtained. This serum was incubated with $\mathrm{C} 3 \mathrm{H}$ ${ }^{59} \mathrm{Fe}$-labeled red blood cells at $37^{\circ} \mathrm{C}$ for $30 \mathrm{~min}$. These red blood cells were injected into the animals with or without pretreatment with non-labeled heat-damaged cells. The survival and organ distribution were observed.

\section{RESUlts}

Table 1 shows the percentage of hepatic and splenic radioactivity $2 \mathrm{hr}$ after injection of ${ }^{59} \mathrm{Fe}$-labeled red blood cells heated at $49^{\circ} \mathrm{C}$ and $52^{\circ} \mathrm{C}$. The splenic activity was significantly higher when the red blood cells were heated at $49^{\circ} \mathrm{C}$ than at $52^{\circ} \mathrm{C}(p<0.005)$. Hepatic activity, however, was not significantly higher after injecting the red blood cells heated at $49^{\circ} \mathrm{C}$ than at $52^{\circ} \mathrm{C}$. Effects of the duration of heat damage at $49^{\circ} \mathrm{C}$ are summarized in Fig. 2 and Table 2 . With regard to the clearance curve no difference was observed between 30 min-heating and $90 \mathrm{~min}$ heating. The spleen-to-liver ratio of radioactivity was maximum when the red blood cells were heated for 30 to $45 \mathrm{~min}$ (no significant difference between 30 and

TABLE 1. Organ distribution of ${ }^{59} \mathrm{Fe}$-labeled, heat-damaged red blood cells

\begin{tabular}{crrc} 
& \multicolumn{1}{c}{$49^{\circ} \mathrm{C}$} & \multicolumn{1}{c}{$52^{\circ} \mathrm{C}$} & Difference \\
\hline Liver & $19.5 \pm 7.2$ & $11.4 \pm 2.8$ & NS \\
Spleen & $27.3 \pm 5.9$ & $12.3 \pm 3.5$ & $p<0.005$ \\
Spleen/liver ratio & $1.4 \pm 0.3$ & $1.1 \pm 0.2$ & NS \\
\hline
\end{tabular}

Red blood cells were damaged by incubation at $49^{\circ} \mathrm{C}$ or $52^{\circ} \mathrm{C}$ for $30 \mathrm{~min}$. Percent of the injected dose is shown. $n=5$, mean $\pm \mathrm{SD}$. NS, not significant. 
$90 \mathrm{~min}$ ). Thus, the red blood cells heat-damaged at $49^{\circ} \mathrm{C}$ for $30 \mathrm{~min}$ were efficiently concentrated into the spleen.

The method of pretreatment with an intravenous injection of heat-damaged red blood cells is shown in Fig. 3. The clearance of ${ }^{51} \mathrm{Cr}$-labeled heat-damaged red blood cells was the same in Group A (the animals were pretreated with nonlabeled red blood cells 72, 48, 24 and $2 \mathrm{hr}$ before infusion of ${ }^{59} \mathrm{Fe}-$ labeled cells), Group

\begin{tabular}{|c|c|c|c|c|c|}
\hline Group & Before $72 \mathrm{hr}$ & $48 \mathrm{hr}$ & $24 \mathrm{hr}$ & $2 \mathrm{hr}$ & $0 \mathrm{hr}$ \\
\hline $\begin{array}{c}\text { Control } \\
\text { A } \\
\text { B } \\
\text { C } \\
\text { D }\end{array}$ & $\downarrow$ & $\downarrow$ & $\begin{array}{l}\downarrow \\
\downarrow \\
\downarrow\end{array}$ & $\begin{array}{l}\downarrow \\
\downarrow \\
\downarrow \\
\downarrow\end{array}$ & $\begin{array}{l}\downarrow \\
\downarrow \\
\downarrow \\
\downarrow\end{array}$ \\
\hline
\end{tabular}

Fig. 1. The method of pretreatment of non-labeled heat-damaged red blood cells. $\downarrow, 0.6$ $\mathrm{ml}$ of heated RBCs; $0.2 \mathrm{ml}$ of ${ }^{51} \mathrm{Cr}$-labeled heated RBCs.

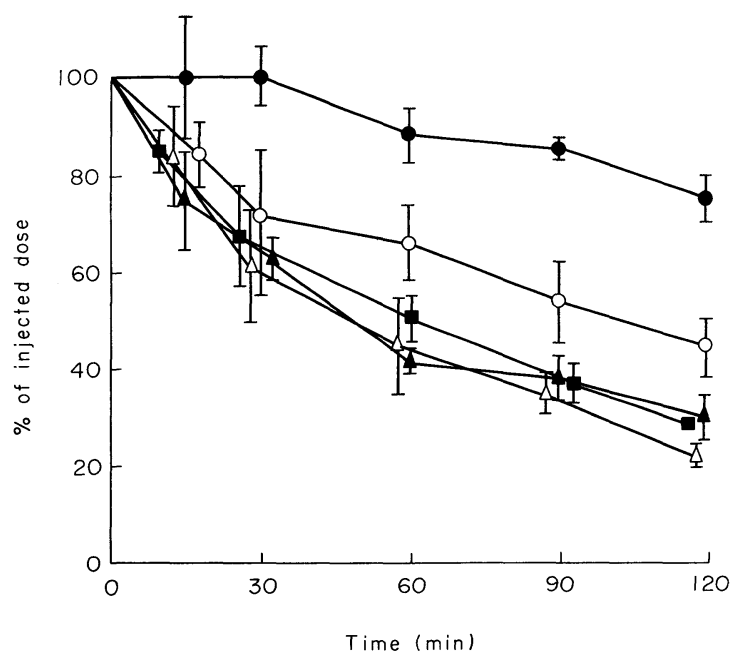

Fig. 2. The clearance of ${ }^{59} \mathrm{Fe}-$ labeled heat-damaged red cells which were incubated at $49^{\circ} \mathrm{C}$ for $5(\bullet-\bullet), 15(\circ-\circ), 30(\Delta-\Delta), 45(\Delta-\Delta)$ and $90 \mathrm{~min}(\bullet-\backsim)$. The clearance curves show no statistical difference between 30 and $90 \mathrm{~min}$ incubations.

TABLE 2. Organ distribution of ${ }^{51} \mathrm{Cr}$-labeled, heat-damaged red blood cells

\begin{tabular}{cccrrr}
\hline & \multicolumn{5}{c}{ Incubation time $(\mathrm{min})$} \\
& \multicolumn{1}{c}{5} & \multicolumn{1}{c}{15} & \multicolumn{1}{c}{30} & \multicolumn{1}{c}{45} & \multicolumn{1}{c}{90} \\
\hline Liver & $3.5 \pm 0.5$ & $15.4 \pm 5.1$ & $16.1 \pm 6.9$ & $10.3 \pm 3.7$ & $8.8 \pm 1.8$ \\
Spleen & $1.6 \pm 0.2$ & $14.6 \pm 0.9$ & $22.5 \pm 4.1$ & $13.0 \pm 0.4$ & $9.5 \pm 1.7$ \\
Spleen/liver ratio & $0.5 \pm 0.1^{*}$ & $1.1 \pm 0.4^{*}$ & $1.5 \pm 0.4$ & $1.5 \pm 0.1$ & $1.1 \pm 0.3$ \\
\hline
\end{tabular}

Red blood cells were damaged by incubation at $49^{\circ} \mathrm{C}$. Percent of the injected dose is shown. $n=5$, mean $\pm \mathrm{SD}$. * Significant difference between 5 and $15 \mathrm{~min}$ values $(p<0.05)$. 
B (the animals were pretreated 48, 24 and $2 \mathrm{hr}$ before infusion), Group C (the animals were pretreated 24 and $2 \mathrm{hr}$ before infusion) and Group D (the animals were pretreated only $2 \mathrm{hr}$ before infusion). Based on these results, it was concluded that the RES was blockaded by the pretreatment $2 \mathrm{hr}$ before infusion.

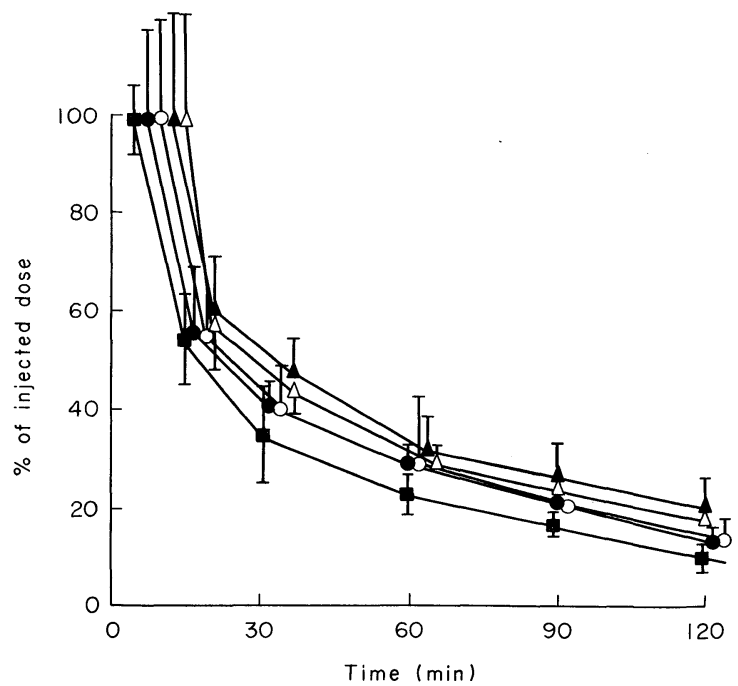

Fig. 3. The clearance of ${ }^{51} \mathrm{Cr}$-labeled, heat-damaged red blood cells with pretreatment of non-labeled, heat-damaged cells in various conditions (see text). $\bullet-\bullet, A$; O-O, B; $\Delta-\Delta, \mathrm{C} ; \Delta-\Delta \mathrm{D} ; \mathbf{-}-\mathbf{-}$, control.

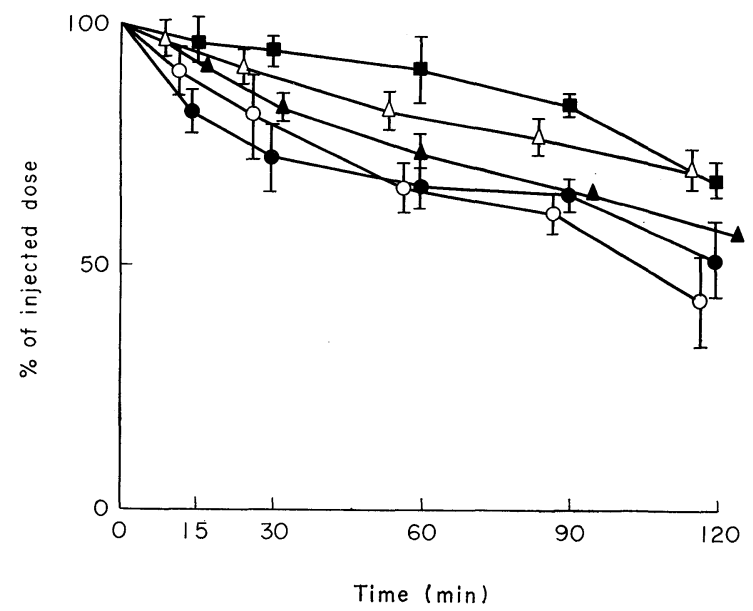

Fig. 4. The clearance of ${ }^{59} \mathrm{Fe}-l a b e l e d$, heat-damaged red blood cells in control (DC $\left.\bullet-\bullet\right)$ and splenectomized mice (DS $0-0)$. Pretreatment with an intravenous injection of non-labeled, heat-damaged cells was done in control (BC $\Delta-\mathbf{\Lambda})$ and splenectomized animals (BS $\Delta-\Delta$ ) (see Table 3). In the RES-blockaded animals, the clearance prolonged in $\mathrm{BC}(0.1<p<0.2)$ and $\mathrm{BS}(p<0.005)$. The effect of RES blockade was most remarkable in the splenectomized animals. The clearance of ${ }^{59} \mathrm{Fe}$-labeled normal red cells is also shown (C a- $\mathbf{a})$. 
Fig. 4 shows the relationship between red blood cell destruction and RES. The clearance of ${ }^{59} \mathrm{Fe}$-labeled, heat-damaged cells in non-splenectomized control animals and splenectomized animals was fast (DC, DS in Fig. 4). In the RESblockaded animals, the clearance prolonged in $\mathrm{BC}$ (statistically not significant, $0.1<p<0.2)$ and BS $(p<0.005)$. The effect of RES blockade was most remarkable in the splenectomized animals. The organ distribution of ${ }^{59} \mathrm{Fe}$-labeled, heatdamaged cells $2 \mathrm{hr}$ after infusion is shown in Table 3 . In the control animals the splenic radioactivity became lower by the RES blockade $(p<0.05)$. In the

TABLE 3. Organ distribution of ${ }^{59} \mathrm{Fe}$-labeled, heat-damaged red blood cells in control and splenectomized mice: Effect of RES blockade

\begin{tabular}{cccccr}
\hline Organ & C & DS & BS & DC & \multicolumn{1}{c}{ BC } \\
\hline Liver & $3.6 \pm 1.0$ & $17.4 \pm 2.2$ & $6.3 \pm 0.6$ & $11.3 \pm 4.1$ & $7.5 \pm 1.6$ \\
Spleen & - & - & - & $17.9 \pm 1.6$ & $13.2 \pm 3.0$ \\
Heart & $0.8 \pm 0.2$ & $0.8 \pm 0.2$ & $0.7 \pm 0.1$ & $1.1 \pm 0.4$ & $0.7 \pm 0.1$ \\
Lung & $2.5 \pm 0.5$ & $6.2 \pm 2.0$ & $4.7 \pm 0.4$ & $3.7 \pm 1.7$ & $3.0 \pm 0.5$ \\
Kidney & $2.2 \pm 1.3$ & $7.5 \pm 1.5$ & $5.6 \pm 0.7$ & $5.0 \pm 0.6$ & $6.4 \pm 0.8$ \\
Bone marrow & $1.7 \pm 0.3$ & $2.7 \pm 0.5$ & $2.5 \pm 0.5$ & $1.8 \pm 0.3$ & $2.3 \pm 0.8$ \\
Spleen/liver ratio & - & - & - & $1.7 \pm 0.4$ & $1.8 \pm 0.2$ \\
\hline
\end{tabular}

C, ${ }^{59} \mathrm{Fe}$-labeled RBCs were infused in control animals; DS, ${ }^{59} \mathrm{Fe}$-labeled, heat-damaged RBCs were infused in splenectomized animals without RES blockade; $\mathrm{BS}$, ${ }^{59} \mathrm{Fe}-$ labeled, heat-damaged $\mathrm{RBCs}$ were infused in splenectomized animals with RES blockade; DC, ${ }^{59} \mathrm{Fe}-$ labeled, heat-damaged RBCs were infused in control animals without RES blockade; BC, ${ }^{59}$ Fe-labeled, heat-damaged RBCs were infused in control animals with RES blockade.

$n=5 ;$ mean $\pm \mathrm{sD}$.

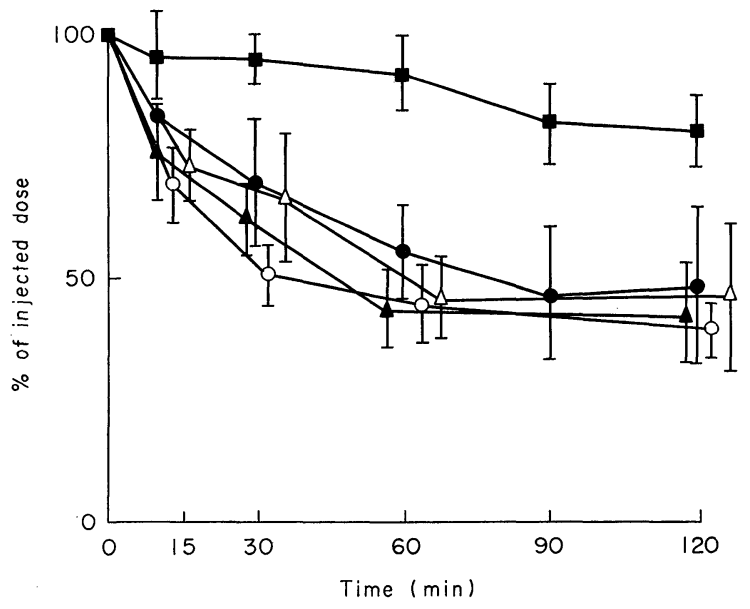

Fig. 5. The clearance of ${ }^{59} \mathrm{Fe}-$ labeled, antibody-coated red blood cells in control (AC •-•) and splenectomized mice (AS O-O). Pretreatment with an intravenous injection of non-labeled, heat-damaged cells was done in control (BAC $\Delta-\mathbf{\Delta})$ and splenectomized animals (BAS $\Delta-\Delta)$. The clearance of ${ }^{59} \mathrm{Fe}$-labeled normal red cells is also shown (C - - (see Table 4). There are no significant differences between control and splenectomized animals with or without blockade. 
TABLE 4. Organ distribution of ${ }^{59} \mathrm{Fe}$-labeled, antibody-coated red blood cells in control and splenectomized mice: Effect of RES blockade

\begin{tabular}{|c|c|c|c|c|c|}
\hline Organ & $\mathrm{C}$ & $\mathrm{AC}$ & BAC & $\mathrm{AS}$ & BAS \\
\hline Liver & $3.9 \pm 0.9$ & $17.6 \pm 3.1$ & $14.0 \pm 2.7$ & $30.0 \pm 4.0$ & $16.2 \pm 2.4$ \\
\hline Spleen & $1.1 \pm 0.2$ & $3.2 \pm 0.9$ & $4.8 \pm 1.4$ & - & - \\
\hline Heart & $0.3 \pm 0.1$ & $0.4 \pm 0.1$ & $0.3 \pm 0.1$ & $0.4 \pm 0.2$ & $0.3 \pm 0.1$ \\
\hline Lung & $2.4 \pm 0.5$ & $2.1 \pm 0.8$ & $1.8 \pm 0.2$ & $2.0 \pm 0.7$ & $1.5 \pm 0.5$ \\
\hline Kidney & 2. $1 \pm 0.7$ & $9.9 \pm 1.5$ & $10.5 \pm 3.5$ & $10.8 \pm 1.4$ & $11.7 \pm 1.5$ \\
\hline Bone marrow & $1.9 \pm 0.3$ & $4.2 \pm 0.6$ & $5.9 \pm 1.1$ & $5.0 \pm 1.5$ & $5.8 \pm 1.8$ \\
\hline Spleen/liver ratio & $0.3 \pm 0.1$ & $0.2 \pm 0.1$ & $0.3 \pm 0.1$ & - & - \\
\hline
\end{tabular}

$n=5 ;$ mean $\pm \mathrm{SD}$.

C, ${ }^{59}$ Fe-labeled RBCs were infused in control animals; AC, ${ }^{59} \mathrm{Fe}-$ labeled, antibody-coated RBCs were infused in control animals without RES blockade; BAC, ${ }^{59}$ Fe-labeled, antibody-coated $\mathrm{RBCs}$ were infused in control animals with RES blockade; AS, ${ }^{59} \mathrm{Fe}-$ labeled, antibody-coated RBCs were infused in splenectomized animals without RES blockade; BAS, ${ }^{59}$ Fe-labeled, antibody-coated RBCs were infused in splenectomized animals with RES blockade.

splenectomized animals, the hepatic radioactivity was depressed by the blockade $(p<0.001)$.

${ }^{59} \mathrm{Fe}-\mathrm{labeled}$ red blood cells treated with anti-C3H-erythrocyte serum disappeared rapidly in control and splenectomized animals with or without the RES blockade (Fig. 5). Table 4 shows the organ distribution of these red cells in various experimental groups. There were no significant differences in organ distribution among these groups, except that the hepatic radioactivity in the splenectomized group was depressed significantly $(p<0.001)$.

\section{Discussion}

The intravascular survival of blood cells was examined in $\mathrm{C} 3 \mathrm{H}$ mice which were either pretreated or not pretreated with heat-damaged red blood cells. The heat-damaged red blood cells are known to blockade the RES (Stuart 1970) and to delay the phagocytosis of ${ }^{59} \mathrm{Fe}-$ labeled heat-damaged red blood cells. These experiments were done in splenectomized and non-splenectomized animals. Effects of the RES blockade, especially the blockade of the splenic RES, on the clearance of the infused red blood cells was confirmed.

The red blood cells used for the RES blockade were prepared by incubating them at $49^{\circ} \mathrm{C}$ for $30 \mathrm{~min}$. These heat-damaged cells were efficiently concentrated into the spleen. The blockade with unlabeled heat-damaged red blood cells $2 \mathrm{hr}$ before the infusion of labeled cells was most effective. Biozzi et al. (1957) showed that the RES blockade by saturation with heat-damaged red blood cells lasted for only a short duration and that it was soon followed by a phase of overactivity.

After the RES blockade, the clearance of ${ }^{59} \mathrm{Fe}-l a b e l e d$ red blood cells was prolonged only when the animals were splenectomized, in advance. This suggests that damaged red blood cells, such as heat-damaged cells, are destructed predominantly by the splenic RES. De Luzio and Wooles (1964) also reported the 
depression of phagocytic activity of the RES after blockade; infused sheep erythrocytes reduced to half (mean half time) at $39 \mathrm{~min}$ after infusion in the blocked mice, while at $11.2 \mathrm{~min}$ in control mice. Buchanan and MacGreger (1964) and Castro et al. (1974) observed prolongation of the survival time of human red blood cells in mice after chemical splenectomy by ethyl palmitate.

For the antibody-coated red blood cells, however, the mechanism of cell destruction does not depend only upon phagocytosis by the splenic RES, because there are no significant correlations between the clearance rates in non-splenectomized control and splenectomized animals. As a significant decrease of hepatic radioactivity was seen in splenectomized animals, antibody-coated red blood cells might be destructed in the splenic and hepatic RES, or by other mechanisms such as intravascular hemolysis.

\section{References}

1) Biozzi, G., Halpern, B.N., Benacerraf, B. \& Stiffel, C. (1957) Physiopathology of Reticuloendothelial System, Blackwell Scientific Publication, Oxford, pp. 204-214.

2) Buchanan, K.D. \& MacGreger, R.F.S. (1964) Prolongation of the survival of human red cells in mice by chemical splenectomy. Brit. J. exp. Path., 45, 248-251.

3) Castro, O., Rosen, M.W. \& Finch, S.C. (1974) Mechanism of ethyl palmitate and cobra venom factor enhancement of heterologous erythrocyte survival. Proc. Soc. exp. Biol. Med., 147, 106-109.

4) De Luzio, N.R. \& Wooles, W.R. (1964) Depression of phagocytic activity and immune response by methyl palmitate. Amer. J. Physiol., 206, 939-943.

5) Murray, I.M. (1963) The mechanism of blockade of the reticuloendothelial system. J. $\exp$. Med., 117, 139-147.

6) Nishioka, H. (1974) The Method of Antibody Formation to Sheep Red Cells. Biochemistry in Immunology. Kyoritsu-Shuppan, Tokyo, pp. 79-80. (Japanese)

7) Stuart, A.E. (1970) Stimulation and depression of the reticuloendothelial system. In: The Reticuloendothelial System, edited by A.E. Stuart, E \& S Livingstone, Edinburgh-London, pp. 89-121. 